\title{
PELATIHAN SISTEM INTEGRASI SAPI DAN AYAM DALAM RANGKA PENINGKATAN PENDAPATAN EKONOMI PETERNAK DI DESA PONAEN KABUPATEN KUPANG
}

\author{
Tara Tiba Nikolaus, I. G. N. Jelantik, Imanuel Benu \\ Fakultas Penternakan UNDANA, Kupang \\ E-mail koresponden : taratibanikolausn@yahoo.com
}

\begin{abstract}
ABSTRAK
Kegiatan pengabdian ini bertujuan untuk melatih masyarakat agar dapat memanfaatkan teknologi integrasi sapi dan ayam sehingga dapat meningkatkan pendapatan peternak skala kecil. Kegiatan ini dilakukan dalam empat tahap yaitu tahap sosialisasi, penyiapan media pelatihan, pelaksanaan pelatihan, dan evaluasi tingkat kepuasan dan minat peserta latih. Pada tahap sosialisasi dilakukan diskusi dengan peternak tentang manfaat penerapan teknologi sapi ayam dan pada akhir tahap ini dipilih 25 peserta yang terdiri dari peternak dan pemuda dari desa Ponaen, Oesena, dan Tesbatan di Kecamatan Amarasi untuk mengikuti pelatihan. Pada tahap penyiapan media pelatihan disiapkan jerami padi sebanyak kurang lebih $200 \mathrm{~kg}$, hijauan lamtoro dan daun kapuk, bahan aditif seperti dedak padi, pollard, urea, dan EM4. Pada tahap pelatihan dilakukan kegiatan penyampaian materi pelatihan berupa teknologi amoniasi dan fermentasi jerami untuk pengolahan pakan, pembuatan silase, sistem integrasi sapi dan ayam, dan penanaman hijauan pakan ternak serta dilanjutkan dengan demonstrasi pembuatan hay dan silase. Hasil evaluasi menunjukkan bahwa seluruh peserta merasa puas dan senang terhadap informasi yang disampaikan selama pelatihan dan berjanji akan menindaklanjuti teknologi yang dilatihkan serta merencanakan untuk mengadakan mesin pencacah hijauan Di samping itu, peserta sangat senang menerima bantuan bibit hijauan pakan ternak berupa bibit lamtoro, Clitoria ternatea dan turi.
\end{abstract}

Kata kunci : Integrasi, Sapi, Ayam, Feses, Larva, Amoniasi, silase 


\section{PENDAHULUAN}

\subsection{Analisis Situasi}

Pengembangan ternak sapi di Propinsi NTT telah dimulai sejak awal tahun 1900an dan telah menjadi tulang punggung pendapatan ekonomi masyarakat. Didukung dengan padang penggembalaan yang mencapai 800 ribu ha (Disnak Provinsi NTT, 2014), Propinsi NTT telah menjadi salah satu daerah sentra produksi ternak sapi nasional. Ternak sapi telah menjadi mata pencaharian utama bagi lebih dari 253 ribu peternak tersebar di berbagai kabupaten terutama di kabupaten kupang.

Sistem pemeliharaan ternak sapi di NTT pada umumnya belum intensif. Sebagian besar lebih dari $92 \%$ peternak masih memelihara ternak sapi dengan cara melepas dan setengahnya bahkan tidak masuk ke dalam atau tidak memiliki kandang. Pada kondisi seperti tersebut, produktivitas ternak sapi pada umumnya rendah. Pendapatan peternak sapi di NTT pada umumnya masih belum optimal disebabkan oleh berbagai faktor termasuk produktivitas ternak yang rendah, rendahnya harga jual dan kapasitas pemeliharaan yang rendah.

\subsection{Permasalahan Mitra}

Kendati ternak sapi telah secara turun-menurun diusahakan oleh sebagian besar (59\%) keluarga petani dan telah menjadi komoditi andalan penyumbang terbesar pendapatan asli daerah (PAD) Nusa Tenggara Timur (Amareko, 1997), produktivitas ternak ini tergolong masih sangat rendah. Survey yang dilakukan oleh Jelantik (2001) mendapatkan bahwa produksi sapi jantan siap jual per tahunnya hanya 9,45\% dari total populasi. Ini berarti bahwa seorang peternak hanya menghasilkan 1 ekor sapi jantan dari 10 ekor sapi yang dipeliharanya. Padahal jumlah pemilikan rata-rata 3,2 ekor yang berarti pula seorang peternak di NTT hanya mampu menjual sapi setiap 3 tahun sekali. Gambaran rendahnya produktivitas ternak sapi ini juga terlihat pada peternak sapi di desa Ponae, Kecamatan Amarasi, Kabupaten Kupang.

Faktor utama penyebab rendahnya produktivitas sapi Bali adalah tingginya tingkat kematian ternak terutama pedet dan rendahnya laju pertumbuhan sapi pada semua tingkatan umur dan jenis kelamin. Beberapa penelitian yang telah diadakan di daerah ini pada umumnya mengungkapkan tingginya angka kematian pedet tersebut di hampir seluruh wilayah NTT dan pada sistem pemeliharaan ternak sapi yang berbeda. Wirdahayati (1989) melaporkan bahwa tingkat kematian pedet pada sapi Bali yang dipelihara secara ekstensif atau semi-intensif di NTT berkisar antara 25 sampai 30\%. Bamualim dkk. (1990), Malessy dkk. (1990) dan Bamualim (1992) mencatat kematian pedet mencapai 47\% dari jumlah yang dilahirkan. Tingkat kematian yang sangat tinggi yaitu lebih dari setengah $(53,3 \%)$ juga pernah dilaporkan (Fattah, 
1998). Survei yang belakangan dilakukan selama 2 tahun berturut-turut pada dua sistem pemeliharaan yang berbeda (gembala dan diikat) juga mengindikasikan bahwa kematian anak sapi masih tetap sangat tinggi (Jelantik, 2001). Dari data-data tersebut bisa dibayangkan tingkat kerugian ekonomis yang telah dialami oleh peternak di daerah ini selama bertahun-tahun. Untuk ukuran desa Ponae dengan populasi ternak sapi diperkirakan mencapai lebih dari 500 ekor, jumlah kematian pedet per tahunnya mencapai 47 ekor dengan asumsi 35,1\% dari 128 ekor yang dilahirkan oleh sekitar 200 ekor betina pada tahun 1998 (Jelantik, 2001). Jika seekor pedet pada umur satu tahun di hargai antara Rp. 800 ribu hingga 1 juta rupiah, maka kerugian yang dialami peternak setiap tahunnya mencapai 38 sampai 47 juta. Sementara untuk skala propinsi Nusa Tenggara Timur, kerugian akibat kematian pedet mencapai 53,17 sampai 66,5 milliar rupiah (Jelantik, 2001). Angka ini merupakan kerugian ekonomis yang sangat besar bagi daerah ini.

Tingginya kematian pedet sapi Bali di pulau Timor nampaknya banyak berhubungan dengan keterbatasan kuantitas susu yang dihasilkan oleh induk yang mengalami stress nutrisi selama musim kemarau. Kelahiran anak sapi Bali di NTT terkonsentrasi selama bulan Juni sampai Agustus atau pada pertengahan musim kemarau (Toelihere dkk., 1990; Jelantik, 2001). Indikasi tingginya pengaruh stress pakan pada kematian pedet di NTT sebagai contoh dapat dilihat dari hasil penelitian yang di lakukan oleh Jelantik (2001). Kematian anak sapi bervariasi antar desa dari 24,1 sampai 51,2\% dan variasi yang besar ini banyak berhubungan dengan kuantitas pakan yang tersedia di padang penggembalaan selama musim kemarau. Pedet yang dilahirkan oleh seekor induk yang mengalami stress pakan akan dibatasi oleh rendahnya produksi susu. Produksi susu sapi Bali pada musim kemarau hanya 0,79 (Wirdahayati dan Bamualim, 1990) sampai 1,4 kg/hari (Jelantik dkk., 1998; Jelantik, 2001). Kondisi yang lebih parah terjadi di daerah pinggiran kodya Kupang. Penurunan kualitas hijauan yang terjadi selama musim kemarau dibarengi oleh penurunan secara cepat luasan padang penggembalaan alam sebagai akibat perluasan perumahan.

Di samping rendahnya produksi anak sapi, efesiensi penggemukan juga tergolong rendah. Hal ini yang membatasi perkembangan industri penggemukan sapi di daerah ini tidak secepat yang diharapkan karena saat ini penggemukan masih dilakukan secara tradisional menggunakan hijauan sebagai pakan utamanya. Penggemukan sebenarnya dapat dilakukan secara cepat dengan pemberian pakan konsentrat karena pertambahan berat badan yang diperoleh jauh lebih tinggi dibandingkan dengan pakan hijauan (Manggol dkk., 2007). Namun demikian aplikasi secara meluas terkendala oleh rendahnya margin yang diperoleh sebagai akibat mahalnya harga konsentrat. Margin industri ini akan meningkat kalau fesesnya dapat digunakan sebagai pakan ayam dan hal ini akan menarik investasi dan mendorong pesatnya perkembangan industri penggemukan sapi. 


\section{SOLUSI DAN TARGET LUARAN}

\subsection{Solusi yang Ditawarkan}

Pemanfaatan kotoran sapi sebagai sumber pakan ternak ayam dapat dipertimbangkan dengan berbagai alasan. Sebagian nutrisi yang ada di dalam pakan tetap utuh dan tidak tercerna oleh ternak sapi sehingga terakumulasi di dalam feses. Sisa pakan tersebut dapat langsung dikonsumsi oleh ayam buras sehingga dapat menghemat pakan yang diberikan. Pemanfaatan kotoran sapi secara langsung sebagai pakan ayam dimungkinkan karena sebagian dari komponen pakan ternak sapi tidak tercerna. Pada umumnya kecernaan pakan ternak sapi berkisar 40\% sampai 80\% (Van Soest, 1994). Beberapa bahan pakan dikenal sebagai tahan fermentasi rumen atau lolos degradasi rumen. Sebagai contoh, degradabilitas karbohidrat jagung di dalam rumen hanya $60 \%$ (Leng, 2003) sehingga sebagian karbohidrat tersebut masih ada di dalam feses. Secara kasat mata, pecahan jagung giling masih terlihat di dalam feses ternak sapi yang mengkonsumsi ransum yang mengandung jagung giling. Demikian juga dengan dedak padi; sebagian protein dedak padi tahan degradasi di dalam rumen dan mempunyai peluang untuk sampai di feses. Di samping itu, kotoran sapi yang telah terurai/terfermentasi dapat menjadi media pertumbuhan larva dan cacing tanah. Larva lalat atau magot telah terbukti mampu menggantikan tepung ikan sepenuhnya pada pakan ikan (Bondari dan Sheppard, 1981). Kotoran sapi mungkin juga mengandung berbagai zat tertentu dan enzym yang bermanfaat bagi ternak ayam. Secara alamiah ayam buras selalu mengais kotoran sapi baik di kandang maupun di padang penggembalaan. Hal ini mengindikasikan bahwa kotoran masih bernilai nutrisi bagi ayam. Praktisi permakultur juga banyak melaporkan bahwa produksi ayam dapat dilakukan semata-mata dari kotoran sapi tanpa perlu memberikan pakan konvensional. Dengan demikian, peternak sapi dapat memperoleh pendapatan tambahan dari penjualan ayam.

Produksi ternak termasuk telur pada tahun-tahun belakangan ini semakin dibatasi oleh peningkatan harga pakan terutama pakan sumber protein. Pakan sumber protein seperti tepung ikan dan bungkil kedelai semakin langka di pasaran yang berdampak pada semakin meningkatnya harga komoditi tersebut. Di lain pihak, kebutuhan pakan tersebut semakin meningkat dari tahun ke tahun dengan semakin tingginya laju perkembangan industri peternakan termasuk ayam buras. Untuk menekan harga ransum yang terus meningkat, maka dibutuhkan upaya untuk menggantikan pakan sumber protein tersebut dengan pakan yang dapat secara murah diproduksi. Salah satu yang cukup potensial adalah menggantikannya dengan tepung larva lalat (Veldkamp et al., 2012; Ncobela dan Chimoyo, 2015; Vantome et al., 2015). Berbagai penelitian yang telah dilakukan antara lain oleh 
Ogunji et al. (2006), Adeniji, (2007) and Agunbiade et al. (2007). Pada umumnya disimpulkan bahwa tepung larva maupun pupa lalat mengandung nutrisi yang memadai untuk menggantikan tepung ikan. Bahkan beberapa penelitian mendapatkan bawa sumber protein alternatif tersebut mempunyai keunggulan terutama dalam hal komposisi asam amino dibandingkan dengan sumber protein yang umumnya digunakan seperti bungkil kedele maupun bunga matahari (De Koning, 2005; Aniebo et al., 2008). Tepung larva lalat bahkan mempunyai konsentrasi histidin dan methionine yang lebih tinggi dibandingkan dengan tepung ikan. Lebih dari itu, larva lalat terbukti tidak memiliki senyawa kimia yang bersifat toksik pada ternak (Makkar et al., 2014; Charlton et al., 2015) dan tidak ada penolakan peternak terhadap pemanfaatannya (Khusro et al., 2012).

Feses ternak sapi yang diberikan pakan konsentrat dapat menjadi media pertumbuhan larva lalat yang baik (Calvert \& Martin, 1969; Teotia \& Miller, 1974; Ogunji et al., 2006; Adeniji, 2007; St-Hilaire et al., 2007). Pada umumnya feses ternak sapi masih mengandung cukup nutrisi untuk perkembangan dan pertumbuhan larva tetapi dapat sangat bervariasi tegantung pada berbagai faktor terutama kualitas pakan yang diberikan. Di samping itu, sebagai nutrisi dan perkembangan larva lalat, kehadiran lalat menurun dengan menurunnya kandungan air dari kotoran (Calvert\& Martin, 1969; Teotia \& Miller, 1974), bahan organik (Calvert \& Martin, 1969), bau (Teotia \& Miller, 1974) dan tekstur (Teotia \& Miller, 1974). Lama simpan kotoran juga mempengaruhi kandungan nutrisinya. Sebagai contoh Flegal et al. (1972) melaporkan penurunan kandungan protein feses ayam dari 30,5\% menjadi 18,3\% dengan meningkatnya lama simpan dari 7 ke 98 hari. Dengan penurunan tersebut maka pemanfaatan kotoran ternak sebagai media tumbuh larva perlu dilakukan sesegera mungkin.

\subsection{Target Luaran}

Pengabdian masyarakat ini akan dilakukan untuk melatih masyarakat dengan target luaran memahami dan meningkatkan keterampilan dalam teknologi integrasi sapi-ayam dalam aspekaspek sebagai berikut :

1. Pengawetan dan pengolahan hijauan pakan ternak dan limbah pertanian untuk menunjang sistem integrasi sapi dan ayam.

2. Pemanfaatan kotoran sapi untuk produksi larva lalat dan pemanfaatannya pada ternak ayam.

3. Pemanfaatan kotoran ternak ayam sebagai pakan ternak sapi 
Dengan penerapan model integrasi sapi dan ayam yang efisien dan dapat diterapkan pada masyarakat peternak skala kecil untuk meningkatkan pendapatan peternak. Model integrasi ini akan secara signifikan meningkatkan produktivitas ternak sapi dan membuka peluang yang besar untuk mewujudkan tekad pemerintah propinsi menjadi propinsi ternak. Secara nasional, hal ini akan memberikan peran nyata dalam pencapaian program swasembada daging nasional.

\section{PELAKSANAAN KEGIATAN}

Kegiatan pengabdian pada masyarakat ini akan dilaksanakan dalam empat tahapan yaitu sosialisasi pada peternak atau kelompok peternak, penyiapan media pelatihan, pelaksanaan pelatihan dan evaluasi tingkat kepuasan dan minat peserta latih.

\subsection{Tahap 1. Sosialisasi}

Kegiatan sosialisasi penerapan teknologi integrasi sapi-ayam dilaksanakan di desa Ponaen, Kecamatan Amarasi, Kabupaten Kupang. Diskusi dilaksanakan pada tingkat peternak tentang manfaat penerapan teknologi integrasi sapi-ayam. Pada akhir kegiatan tersebut kemudian didata calon peserta pelatihan sebanyak 25 orang yang terdiri dari peternak dan pemuda yang memelihara ternak sapi dari beberapa desa di Kecamatan Amarasi..

\subsection{Tahap 2. Penyiapan Media Pelatihan Sistem Integrasi Sapi dan Ayam}

Dalam rangka pelaksanaan pelatihan sistem integrasi sapi dan ayam, maka dilakukan persiapan bahan dan modul pelatihan. Bahan-bahan yang dipersiapkan antara lain pengadaan limbah pertanian berupa jerami padi, hijauan pakan, tempat pembesaran larva dan pengadaan drum silo. Sebanyak 1 mobil pick-up jerami padi atau sekitar $200 \mathrm{~kg}$ dipersiapkan pada satu hari sebelum pelaksanaan pelatihan. Di samping itu, juga disediakan hijauan pakan berupa daun lamtoro dan daun kapuk. Bahan-bahan penambah (aditif) untuk fermentasi limbah pertanian antara lain dedak padi, pollard, urea, mineral, serta bibit-bibit tanaman pakan yang akan dibagikan kepada masyarakat. 

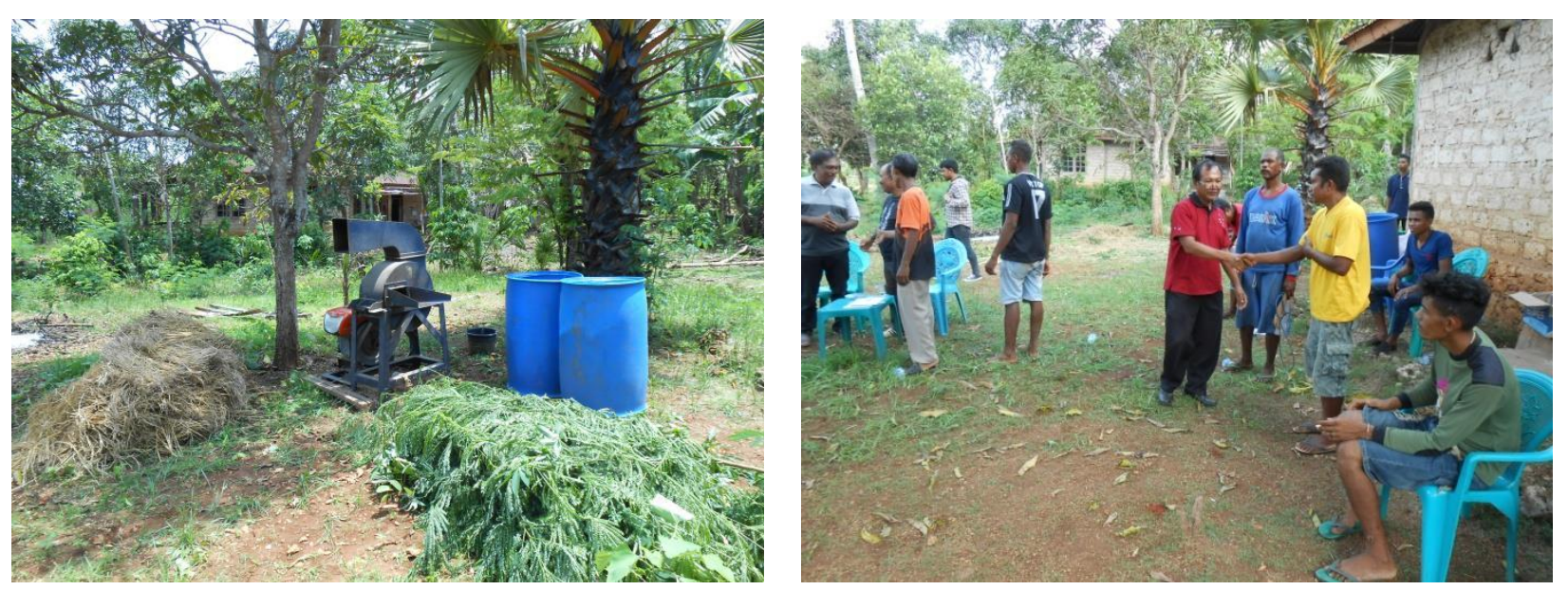

Gambar 1. Penyiapan bahan dan peralatan pelatihan

\subsection{Tahap 3. Pelatihan}

Pelatihan pengolahan dan pengawetan pakan dalam rangka menunjang sistem integrasi sapi dan ayam dilaksanakan di Desa Ponaen, Kecamatan Amarasi dilakukan pada hari Sabtu 8 Desember 2018 dari jam 08.00 sampai jam 18.00. Jumlah peserta yang ikut mencapai 25 orang terdiri dari peternak yang berasal dari desa Ponaen, Oesena dan Tesbatan. Kegiatan pelatihan yang dilakukan meliputi penyampaian materi pelatihan berupa teknologi amoniasi dan fermentasi jerami untuk pengolahan pakan, pembuatan silase, sistem integrasi sapi dan ayam, dan penanaman hijauan pakan ternak.

\subsubsection{Amoniase Jerami}




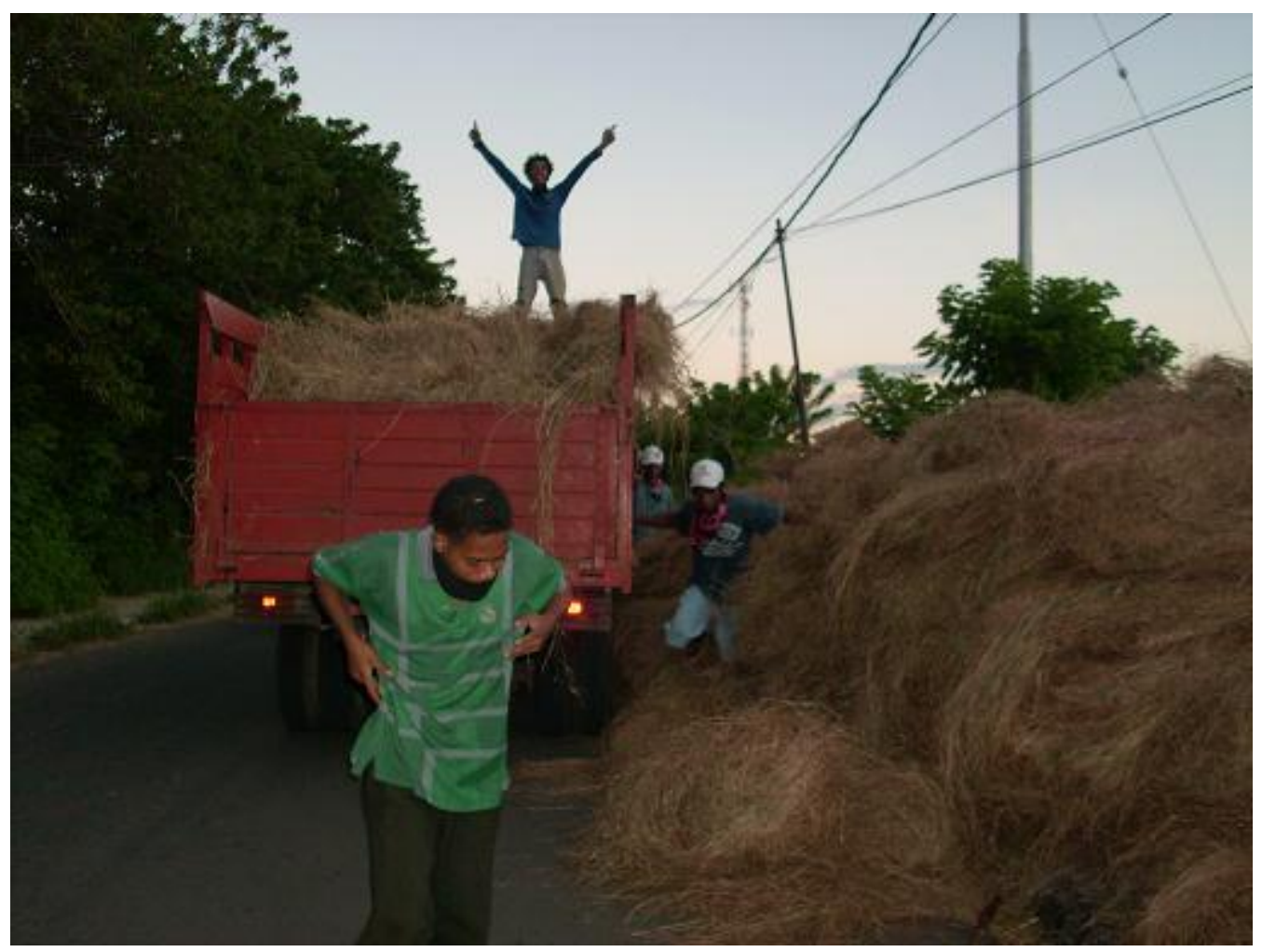

Gambar 2 : Jerami, Pakan Berkualitas Rendah Tetapi Sangat Berguna Untuk Ternak Sapi

Jerami padi adalah salah satu limbah pertanian yang masih dapat dimanfaatkan sebagai pakan ternak. Nilai nutrisi jerami padi pada umumnya rendah. Sebagaimana tanaman yang telah tua, jerami padi memiliki kandungan protein yang rendah dan sebaliknya kandungan serat yang tinggi . Di antara limbah pertanian lainnya, jerami padi mengandung protein paling rendah (tabel 1). Di samping itu jerami padi juga sangat sedikit mengandung mineral yang sangat dibutuhkan oleh ternak seperti sulfur. Sebagai akibatnya, ternak tidak mampu memakan jerami dalam jumlah banyak. Konsumsi jerami dengan ME sekitar $6 \mathrm{MJ} / \mathrm{kg}$ bahan kering hanya mencapai 1,5\% dari berat badan ternak sapi. Sapi yang beratnya $200 \mathrm{~kg}$ hanya mampu makan sekitar 3-4 kg saja per hari. Makanan sejumlah itu hanya cukup untuk memenuhi sekitar 1/3 dari kebutuhan ternak untuk energi. Artinya, kalau makanannya hanya jerami saja maka ternak akan kurus. 
Tabel 1. Nilai nutrisi limbah pertanian

\begin{tabular}{|l|l|l|l|l|l|}
\hline No. & Limbah Pertanian & $\begin{array}{l}\text { Bahan } \\
\text { Kering } \\
(\%)\end{array}$ & CF $(\%)$ & Protein & ME (MJ/kg) \\
\hline 1. & Jerami padi & 65 & 33.0 & 5.2 & 6.8 \\
\hline 2. & Jerami jagung & 58 & 33.9 & 6.0 & 7.2 \\
\hline 3. & Jerami Kc. Hijau & 28 & 20.8 & 23 & 11.1 \\
\hline 4. & Jerami kc. Tanah & 35 & 19.2 & 21 & 10.2 \\
\hline 5. & Jerami Sorghum & 85 & 44.6 & 10.9 & 7.7 \\
\hline 6. & Daun Ubi jalar & 11 & 27.8 & 13 & 10.4 \\
\hline 7. & Pucuk Ubi Kayu & 21 & 15.7 & 27 & 12.3 \\
\hline
\end{tabular}

Sumber : primer, hasil analisis Laboratorium Kimia Pakan Fapet Undana

Walaupun kualitasnya rendah, jerami padi adalah pakan yang sangat berguna bagi ternak sapi selama musim kemarau. Untuk sapi-sapi yang digembalakan, pemberian jerami padi sebagai pakan tambahan selama musim kemarau sangat membantu untuk mempertahankan kondisi ternak sapi untuk tetap sehat dan beranak dengan baik. Kenyataan yang dapat kita catat adalah produktivitas ternak sapi yang digembalakan di lahan-lahan persawahan setelah panen lebih baik dibandingkan dengan sapi yang hanya digembalakan di padang penggembalaan alam. Perbedaan tersebut disebabkan oleh adanya jerami padi yang tersisa di sawah-sawah dan dimakan oleh ternak selama musim kemarau. Sehingga, pemanfaatan jerami padi tanpa pengolahan mungkin lebih cocok digunakan untuk pemeliharaan ternak dengan tujuan produksi anak.

Untuk dapat diberikan pada sapi yang digemukkan, maka jerami padi perlu diolah sehingga kualitasnya menjadi lebih baik setara dengan rumput alam. Di beberapa negara seperti Bangladesh dan China jerami yang telah mengalami proses ammoniasi merupakan sumber hijauan pokok bagi sapi yang digemukkan.

Berbagai teknologi pengolahan dapat diterapkan sehingga meningkatkan nilai manfaat limbah pertanian bagi ternak terutama limbah pertanian jerami padi. Pengolahan limbah pertanian terutama jerami padi dimaksudkan untuk meningkatkan daya guna jerami padi sebagai sumber pakan terutama bagi ternak ruminansia. Daya guna jerami padi dapat diekspresikan dari meningkatnya total konsumsi maupun meningkatnya nilai cerna jermi akibat proses pengolahan. Pengolahan pakan diperlukan untuk berbagai alasan antara lain : 
a. Meningkatkan kualitas pakan yang berkualitas rendah. Banyak jenis pakan berkualitas sangat rendah sehingga tidak dapat digunakan sebagai pakan ternak yang memadai. Hijauan pakan seperti rumput yang sudah tua atau limbah pertanian seperti jerami padi, jerami jagung dan yang lainnya mengandung fraksi serat yang tinggi dan protein yang rendah sehingga tidak layak untuk pakan ternak. Pengolahan pakan seperti ini akan meningkatkan kualitas pakan tersebut sehingga dapat meningkatkan produksi ternak.

b. Pengolahan pakan juga dimaksudkan memperbaiki struktur fisik pakan sehingga lebih diterima oleh ternak.

c. Melengkapi unsur nutrisi yang kurang pada jenis pakan tertentu dengan jenis pakan lainnya.

d. Meramu pakan dalam bentuk pakan komplit sehingga dapat memenuhi kebutuhan nutrisi sesuai dengan tingkat produksi yang diharapkan.

Pengolahan pakan dapat dilakukan dengan berbagai cara antara lain :

a. Secara biologis : mengolah pakan dapat dilakukan menggunakan jamur atau mikroba lainnya.

b. Secara kimia : dapat dilakukan dengan menggunakan bahan-bahan kimia seperti ammonia, $\mathrm{NaOH}$, abu dapur, kapur, urin, dsb.

c. Secara fisik : pencincangan, penggilingian, pengukusan serta iradiasi. Pengolahan secara fisik akan memberikan dampak antara lain meningkatkan konsumsi, memudahkan pemberian pada ternak dan memudahkan pencampuran bahan pakan dalam pembuatan ransum. 


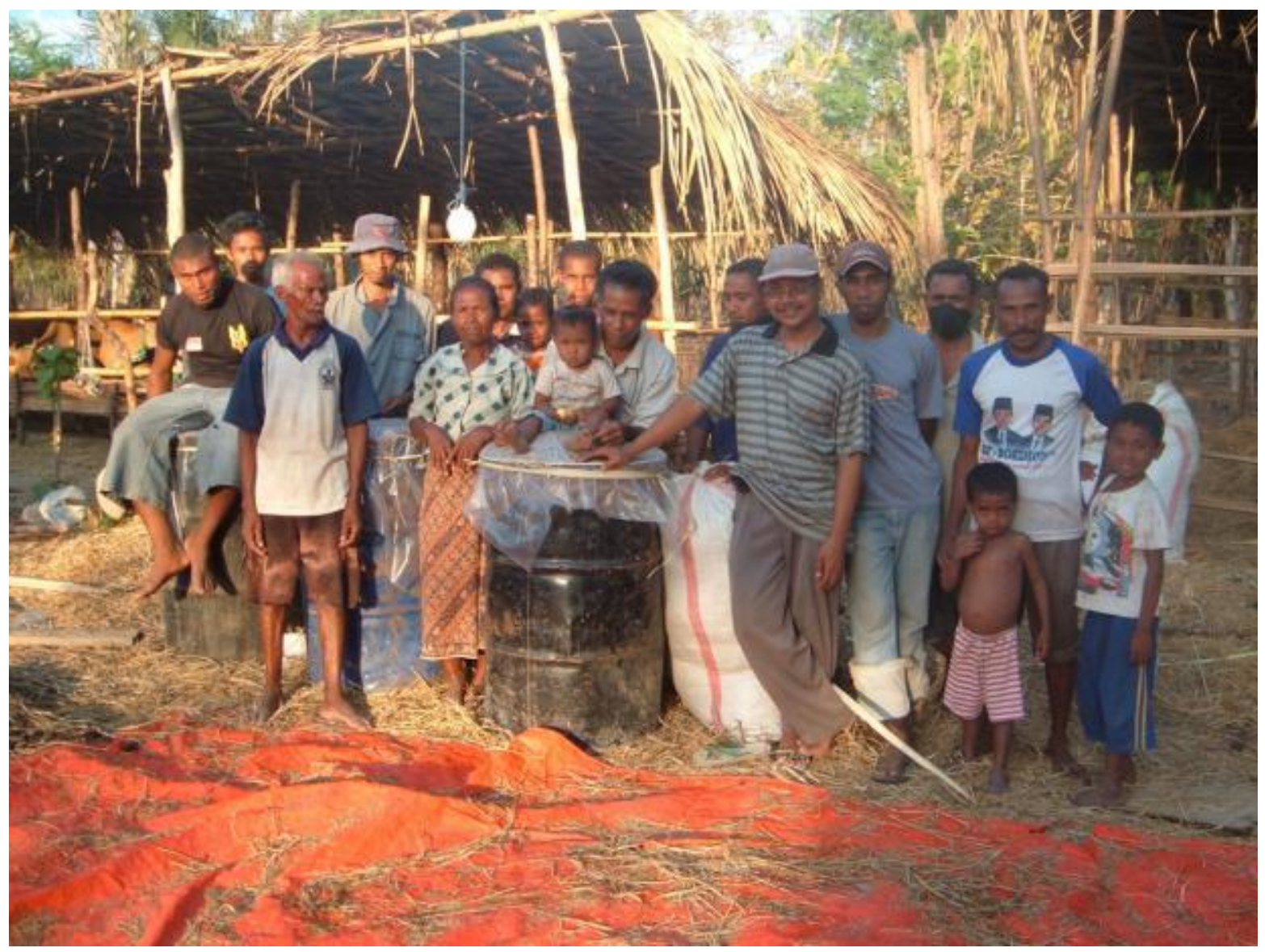

Gambar 3 : Jeram padi yang telah diamoniasi dan disimpan dalam drum

Amoniasi merupakan salah satu teknologi yang dapat digunakan dalam rangka meningkatkan kandungan nitrogen dan meningkatkan daya guna jerami padi. Amoniasi merupakan salah satu metode pengolahan bahan pakan khusunya jerami padi dengan menggunakan gas amoniak atau senyawa yang menghasilkan amoniak. Salah satu senyawa penghasil amoniak adalah urea. Urea merupakan senyawa yang mudah diperoleh di daerah pedesaan dan dapat digunakan dalam proses amoniasi. Pada kondisi cukup air, mikrobia seperti micrococcus Sp., Proteus Sp yang terdapat pada jerami padi akan menghasilkan enzim urease yang mampu mendegradasi urea membentuk senyawa amonium seperti amonium karbonat, amonium bikarbonat, dan amonium hidroksida yang kemudian berpenetrasi ke dalam jerami padi akibatnya kandungan nitrogen jerami padi meningkat. Peningkatan kandungan nitrogen ini penting artinya dalam memenuhi kebutuhan nitrogen bagi sintesis protein mikroba rumen guna memenuhi 
kebutuhan protein bagi ternak. Disamping itu, amonium yang terpenetrasi akan melemahkan ikatan lignin dan selulosa dan menyebabkan pengembangan selulosa sehingga mempermudah penetrasi enzim selulase dan hemiselulase yang dihasilkan mikroba rumen sehingga meningkatkan kecernaan jerami padi. Jadi melalui proses amoniasi, pemanfaatan jerami padi oleh ternak akan semakin meningkat sehingga dapat meningkatkan produktivitas ternak.

Kualitas jerami pada hasil amoniasi tergantung pada varietas jerami padi yang digunakan, konsentrasi urea, volume air dan lama pemeraman. Umunya konsentrasi optimum urea yang digunakan dalam proses amoniasi adalah sebesar $4 \%$ dari total BK jerami padi. Lama pemeraman untuk proses amoniasi adalah 2 minggu yang selanjutnya sudah dapat dimanfaatkan sebagai sumber pakan bagi ternak sapi.

\section{Cara Pembuatan}

\section{Siapkan urea sesuai kebutuhan}

Urea adalah salah satu bahan yang dapat digunakan untuk membuat jerami amoniasi. Urea mengandung nitrogen yang sangat tinggi dan akan diuraikan oleh enzim yang ada di dalam jerami menjadi amoniak yang selanjutnya akan berperan sebagai pelonggar serat dalam jerami. Kalau tidak ada urea dapat digantikan dengan urin atau air kencing atau kotoran ayam tetapi perlu konsentrasi yang lebih banyak.

Banyaknya urea yang dibutuhkan adalah sebanyak $4 \mathrm{~kg}$ untuk setiap $100 \mathrm{~kg}$ jerami padi atau 4\%. Sebelum pembuatan jerami amoniasi, larutkan $4 \mathrm{~kg}$ urea ke dalam 35-50 kg air dan aduk sampai betul-betul larut. Diamkan beberapa saat sambil menyiapkan jerami padi yang akan dibuat menjadi amoniasi.

\section{Siapkan Jerami Padi}

Timbang jerami padi sebanyak $100 \mathrm{~kg}$ atau bisa juga diperkirakan saja. Jerami yang dipakai bisa kering atau segera setelah panen padi. Jerami dapat dicincang dengan ukuran 2-4 cm atau tidak dicincang. Pencincangan akan membantu dalam pemadatan dan mempercepat proses amoniasi. 


\section{Percikkan Larutan Urea pada Jerami}

Larutan urea dipercikkan secara merata pada jerami sambil di aduk-aduk sebelum dimasukkan ke dalam wadah/drum. Lakukan pemadatan pada wadah yang digunakan.

Tutup Wadah Amoniasi dan Penyimpanan

Tutup wadah/drum dengan plastik atau terpal dan diikat kuat. Simpan drum pada tempat yang terhindar dari sinar matahari langsung.

Cara Pemberian Pada Ternak

Setelah 4 minggu, jerami amoniasi sudah dapat diberikan pada ternak. Ciri-ciri jerami amoniasi yang baik adalah: berwarna coklat gelap, tekstur lebut, dan berbau amoniak. Setelah 4 minggu rumput sudah dapat diberikan kepada ternaknya dengan cara :

a. Keluarkan sebanyak yang dibutuhkan setiap harinya

b. Angin-anginkan selama 6-12 jam untuk menghilangkan bau dan sisa ammonia

c. Berikan sebanyak setengah dari kebutuhan makanan ternak yaitu :

- $\operatorname{Anak}(<1$ tahun $): 1-2 \mathrm{~kg} / \mathrm{hari}$

- $\operatorname{Remaja~(<2~tahun)~:~2-4~kg/hari~}$

- Dewasa (> 2 tahun) : 4-6 kg/hari

\section{Pembuatan Dan Pemanfaatan Silase Hijauan}

Pengawetan hijauan pakan atau limbah pertanian dalam bentuk silase merupakan salah satu alternative yang dapat ditempuh terutama untuk mengatasi kesulitan pengadaan pakan di daerah yang mengalami musim kemarau panjang.

Perubahan musim akan mempengaruhi kualitas hijauan pakan yaitu pada musim kemarau yang paling menonjol adalah hilangnya fraksi yang mudah larut atau fraksi non struktural. Hal tersebut disebabkan karena temperatur tinggi akan menyebabkan respirasi meningkat dan akan mengakibatkan penurunan produk netto fotosintesis. Peningkatan laju fotosintesis menyebabkan ratio isi sel dan dinding sel semangkin kecil. Untuk mengatasi masalah tersebut maka pada saat laju pertumbuhan tanaman mencapai produksi dan kualitas tertinggi yaitu pada saat tanaman menjelang berbunga perlu perhatian dalam pengelolaannya melalui teknologi yang sederhana dan mudah dilaksanakan oleh peternak. Teknologi yang dimaksud adalah teknologi silase yaitu suatu teknologi pengawetan hijauan pakan melalui proses fermentasi. 


\subsubsection{Silase}

\section{Cara Praktis Pembuatan}

\section{a. Bahan yang dibutuhkan}

Dalam pembuatan silase, bahan baku yang dapat digunakan adalah semua jenis hijauan yang dapat dikonsumsi ternak, seperti; berbagai jenis rumput (rumput kume, lapangan, rumput raja, rumput gajah, dll), berbagai jenis legum (lamtoro, turi, gamal, dll), dan bahkan limbah pertanian (batang-daun jagung, jerami padi), dll.

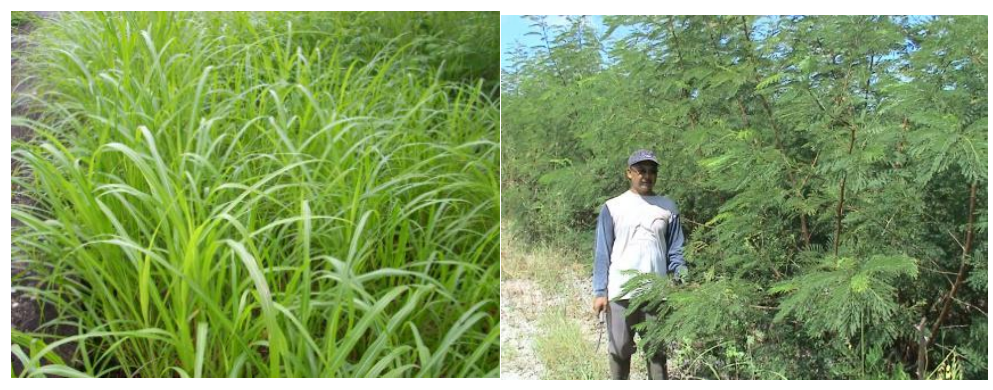

Gambar 4. Hijauan sebagai bahan baku silase

Selain bahan baku utama berupa hiajauan ataupun limbah pertanian, adanya bahan tambahan akan sangat berguna dalam rangka mempercepat proses fermentasi dan menghasilkan $\mathrm{pH}$ silse yang rendah dan mengurangi kehilangan nutrien dari silase. Bahan tambahan yang digunakan sebaiknya yang mudah diperoleh dan murah, seperti dedak, onggok, jagung, dll.

Penambahan EM4 sebagai inoculant juga akan sangat membantu kecepatan laju fermentasi sehingga silase yang baik dapat diproduksi dalam waktu yang relatif lebih cepat.

\section{b. Peralatan}

Peralatan yang dibutuhkan dalam pembuatan silase tergantung dari skala dan kecepatan waktu produksi yang dibutuhkan. Namun demikian, peralatan yang sangat sederhana dapat digunakan dalam membuat dan memproduksi silase. Peralatan sederhana yang dapat dimanfaatkan membuat silalse adalah alat pencacah (parang ataupun mesin cincang), wadah yang akan digunakan sebagai silo (plastik, drum ataupun bak), timbangan (jika ada) dan pentup atau perekat atau tali yang akan digunakan untuk menutup silo. 


\section{c. Cara Pembuatan}

\section{Memotong Hijauan}

Dalam pembuatan silase, pertama-tama peternak harus memotong hijauan. Pada beberapa limbah pertanian hal ini tidak diperlukan karena sudah dipotong pada saat memanen tanaman pangan.

\section{Peralatan Memotong Hijauan}

Memotong hijauan (rumput) dapat dilakukan dengan berbagai peralatan baik yang sederhana maupun yang canggih. Peralatan yang biasan digunakan antara lain : sabit, parang, mesin potong rumput sampai pada buldoser pemotong rumput (mower). Peralatan yang digunakan sangat menentukan banyaknya hijauan yang dapat dipotong pada satuan waktu tertentu sehingga akan menentukan banyaknya rumput yang diperoleh dalam satuan waktu tertentu.

\section{Memotong Hijauan Menggunakan Sabit}

Sabit adalah salah satu peralatan yang paling sederhana yang biasa digunakan untuk memotong rumput. Terdapat bermacam-macam sabit yang biasa dipakai oleh petani/peternak di NTT untuk berbagai kebutuhan dalam memotong/memanen hasil pertanian. Paling tidak ada dua macam sabit yaitu sabit yang bermata pisau polos dan bergerigi. Sabit bermata polos pada umumnya dibuat di NTT sementara sabit bergerigi dibuat di luar NTT seperti Pulau Jawa dan Bali. Di NTT, beberapa sabit dibuat di beberapa daerah di pulau Sabu, Timor, Flores dan Rote. Bentuknya berbeda-beda semuanya memiliki mata pisau polos. Tergantung kebiasaan memotong, beberapa sabit mempunyai kapasitas memotong yang lebih tinggi dibandingkan dengan sabit lainnya. Bentuk sabit yang unik yaitu mempunyai dua pola cekung dan kembung pada satu sisi pisau potongnya menyebabkan mempunyai kecepatan memotong yang sangat tinggi. Namun demikian, sabit jenis ini hanya bisa diayunkan ketika memotong sehingga akan sangat baik digunakan di lahan yang tidak berbatu-batu. Sementara itu jika digunakan pada lahan yang berbatu maka sabit akan mudah rusak. Pada lahan yang berbatu sabit yang mempunyai garis pisau cekung saja yang akan lebih efektif.

Sementara itu sabit bergerigi banyak digunakan di pulau Jawa dan Bali untuk berbagai keperluan terutama dalam memanen padi dan memotong rumput di pematang-pematang sawah. Sabit jenis ini memotong dengan cara menariknya. 


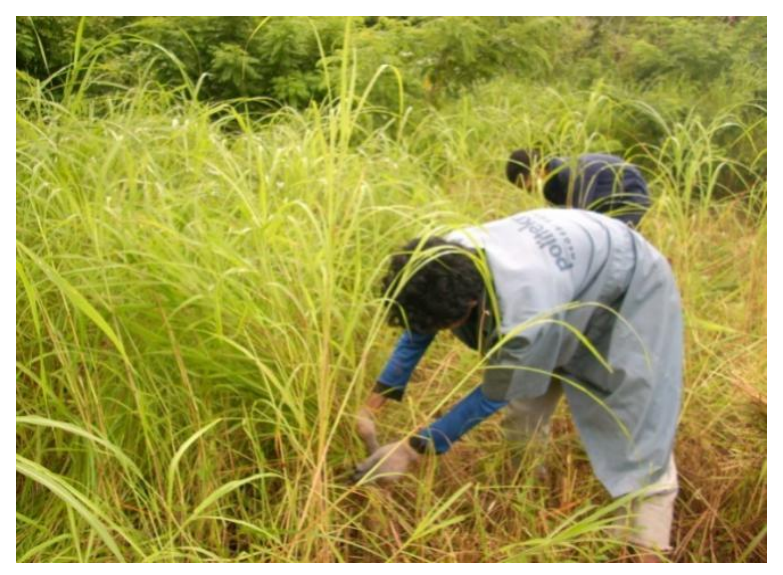

Gambar 5. Memotong Rumput dengan sabit

Memotong rumput menggunakan sabit mungkin merupakan cara memotong hijauan pakan yang paling mungkin dilakukan oleh peternak di NTT. Hal ini disebabkan kemampuan peternak yang rendah. Secara ekonomi sebagian besar peternak kita masih belum mampu membeli peralatan potong hijauan bermesin. Di samping itu, dengan jumlah pemilikan ternak sapi dan ternak lainya yang sedikit sehingga menjadi tidak ekonomis memiliki alat potong bermesin.

Kendati hanya mengandalkan tenaga, sebenarnya memotong hijauan dengan menggunakan sabit cukup efektif. Jumlah yang bisa dipotong bisa sangat besar dan cukup untuk membuat silase yang mampu memenuhi beberapa ekor sapi dalam waktu lama (terutama selama musim kemarau). Namun demikian tergantung pada ketinggian dan ketebalan rumput yang dipotong, umur hijauan dan pengalaman, jumlah hijauan yang berhasil dipotong dapat mencapai $400 \mathrm{~kg}$ sampai 2 ton per hari. Pengalaman penulis dengan menggunakan sabit bergerigi dapat memotong rumput kume pada masa vegetatif selama bulan Maret dapat mencapai 2 ton per hari.

\section{Memotong hijauan dengan mesin pemotong}

Jika peternak ingin membuat silase dalam jumlah besar maka disarankan untuk membeli mesin pemotong rumput yang banyak dijual di toko-toko peralatan mesin. Harga mesin tersebut berkisar antara 1,5 sampai 3,5 juta rupiah tergantung pada merek. Harga lebih banyak menentukan pada kekuatan mesin dan daya tahan mesin tersebut jika digunakan dalam jangka waktu lama. Pengalaman penulis mesin potong rumput dengan harga termurahpun masih dapat digunakan bertahun-tahun (sampai 5 tahun). Bagi peternak yang mulai menggunakan mesin pemotong rumput untuk membuat silase mungkin ada baiknya membeli mesin dengan harga murah untuk menurunkan biaya produksi silase. Sementara itu, bagi peternak yang berencana 
membuat silase sebagai usaha bisnis, maka disarankan untuk membeli mesin dengan merek yang sudah dikenal kekuatannya.

Kapasitas mesin pemotong rumput tersebut sangat tergantung pada orang yang mengoperasikannya. Di samping itu tentu saja sangat tergantung pada tinggi dan ketebalan rumput sehingga dipengaruhi oleh umur tanaman dan kadar air rumput yang dipotong. Orang yang berpengalaman dapat memotong rumput dengan cepat hingga mendekati $1 / 2$ ha per hari. Dengan kecepatan itu rumput yang berhasil dipotong dapat mencapai 8-12 ton per hari. Jika kadar air rumput yang dipotong tersebut $80 \%$ maka jumlah yang berhasil dibuat adalah mencapai 1-2 ton per hari. Artinya, jika digunakan sebagai suplemen bagi ternak selama musim kemarau maka per harinya dapat menghasilkan hay untuk memenuhi kebutuhan ternak sebanyak 3 ekor selama 4 bulan selama musim kemarau.

\section{Memotong dengan menggunakan mower}

Di negara-negara yang sudah maju dimana hay dan silase merupakan pakan utama ternak sapi, peternak pada umumnya memotong rumput dan hijauan lainnya dengan menggunakan tractor pemotong rumput (mower). Mower ini mempunyai kemampuan luar biasa dalam memotong rumput. Dalam sekejap berha-ha lahan dapat dipotongnya. Mower akan sangat efisien digunakan untuk memotong hijauan pada lahan yang datar dan sangat luas dengan tanah yang tidak berbatu. Untuk alasan tersebut, nampaknya peternak di Indonesia khususnya di NTT hampir tidak mungkin untuk menggunakannya untuk membuat silase ataupun hay. Disamping itu, dengan harga yang sangat mahal dan jumlah pemilikan ternak yang kecil membuat peralatan ini tidak cocok digunakan di NTT.

\section{Mencincang Rumput atau Hijauan dan Pelayuan}

Setelah pemotongan rumput, proses pembuatan silase dilanjutkan dengan pencincangan rumput atau hijauan. Pencincangan ini sangat penting oleh karena semakin kecil ukuran silase maka akan semakin menjamin minimnya ruang bagi udara/oksigen ketika diisi, dipadatkan dan ditutup ke dalam silo.

Jika hijauan yang banyak mengandung air sebaiknya dilayukan terlebih dahulu. Pastikan kandungan air dari hijauan yang akan dimasukan ke dalam silo berkisar 70-80\%. Pelayuan dapat dilakukan dengan mengangin-anginkan hijauan selama setengah hingga dua jam bahkan setengah hari bagi jenis rumput yang memiliki kandungan air yang sangat tinggi. Untuk 
mempercepat pelayuan, hijauan sebaiknya jangan ditumpuk secara berlebihan. Tumpukan hijauan sebaiknya hanya berkisar $10-20 \mathrm{~cm}$.

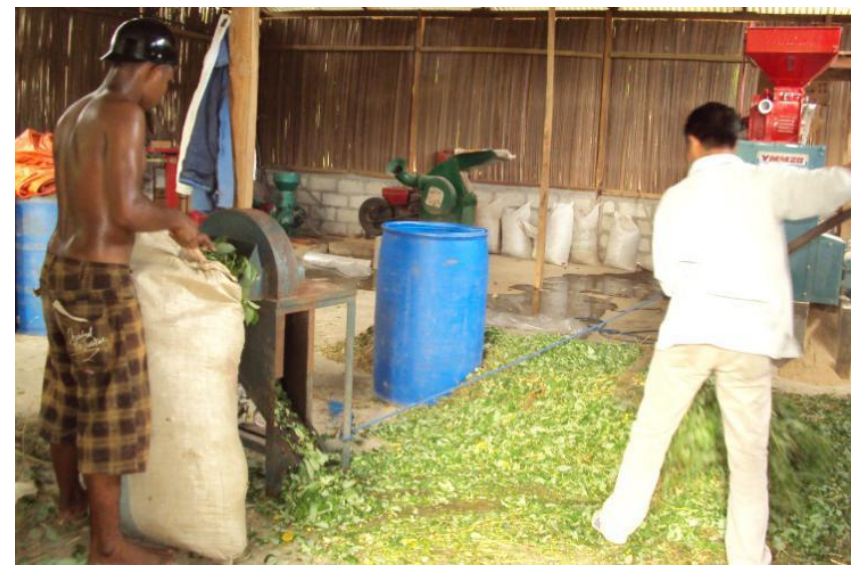

Gambar 6. Pencincangan dan Pelayuan Hijauan

\section{Pencampuran dengan bahan adtif dan atau inoculant}

Pencampuran hijauan dengan bahan aditif dan inoculant dilakukan segera sebelum memasukan hijauan kedalam silo. Jumlah penambahan bahan aditif dapat disesuaikan dengan pertimbangan harga bahan aditif tersebut. Tambahan $3-5 \%$ bahan aditif akan sangat membantu mempercepat proses fermentasi bahkan menambah nilai nutrisi silase yang akan dihasilkan. Penambahan bahan aditif yang melebihi prosentase tersebut juga diperbolehkan dalam membuat silase komplit yang memilki nilai nutrisi yang lebih baik.

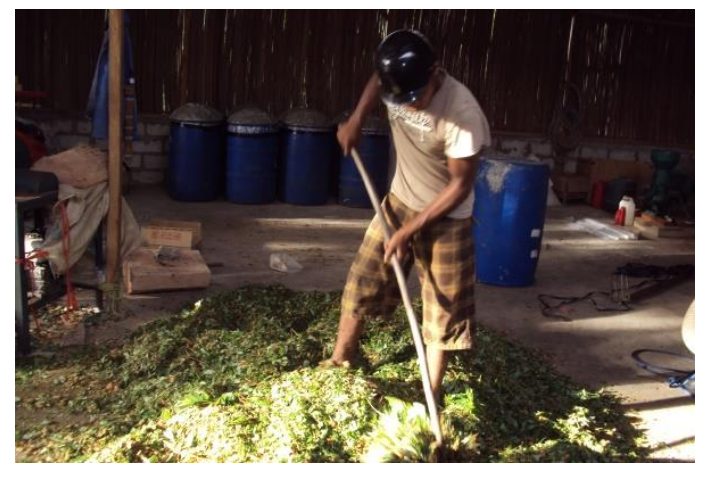

Gambar 7. Pencampuran Hijauan dengan bahan aditif 


\section{Pengepakan atau penyimpanan ke dalam Silo}

Pemasukan dan pemadatan hijauan ke dalam silo sebaiknya dilakukan segera setelah hijauan dicampur dengan bahan aditif dan inoculant. Setelah hijauan dimasukan dan dipadatkan ke dalam silo, tutup rapat-rapat silo. Pastikan wadah yang digunakan sebagai silo tidak bocor sehingga menjamin tidak adanya sirkulasi udara ke dalam silo.

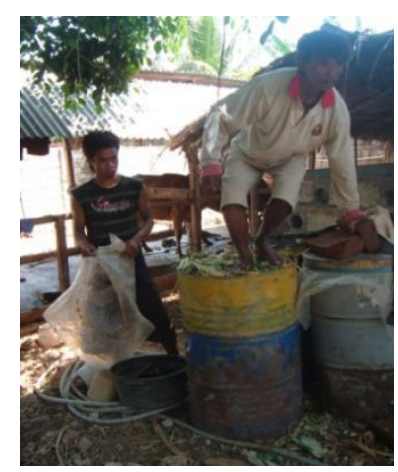

Gambar 8. Pengisian dan Pemadatan Hijauan ke dalam Silo

\section{Cara Pemberian pada Ternak}

Setelah kurang lebih 2 sampai 3 minggu, silo sudah dapat di buka dan silase sudah digunakan untuk diberikan kepada ternak sesuai dengan kebutuhan. Silase yang baik memilki ciri-ciri; berwarna hijau kekuningan, memiliki pH 3,8 - 4,2, teksturnya lembut dan bila dikepal tidak keluar air dan bau busuk, kandungan air berkisar 60 - 70\% dan berbau khas wangi silase.

Namun demikian, sebaiknya sebelum diberikan kepada ternak, silase perlu diangin-anginkan terlebih dahulu hingga bau asamnya hilang, dan kemudian dapat diberikan sedikit demi sedikit hingga ternak mau mengkonsumsinya. 


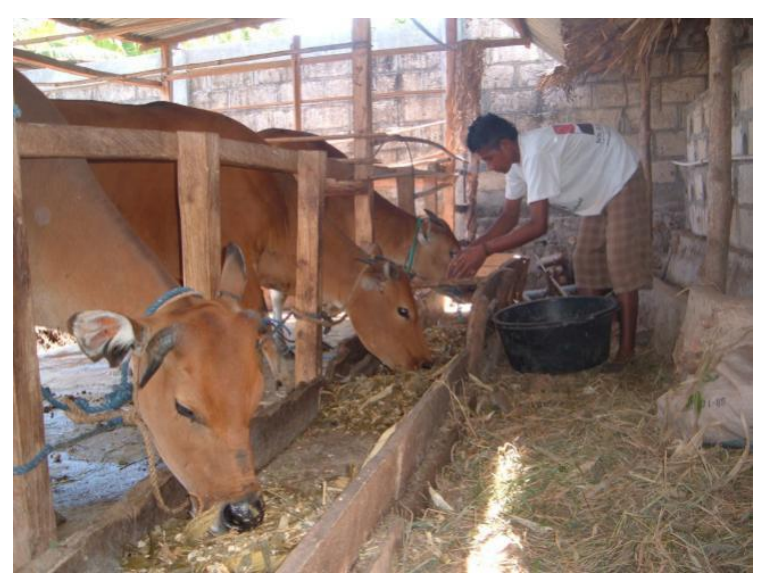

Gambar 9. Pemberian Pakan Silase pada ternak

\section{Tahap 4. Evaluasi}

Kegiatan pelatihan integrasi ternak sapi dan ayam diakhiri dengan evaluasi terhadap pelaksanaan kegiatan dan respons peserta terhadap berbagai materi yang dilatihkan. Hasil evaluasi menunjukkan bahwa seluruh peserta merasa puas dan senang terhadap informasi yang disampaikan selama pelatihan. Di samping itu, peserta latih telah berjanji akan menindaklanjuti teknologi yang dilatihkan. Disamping itu, peternak juga merencanakan untuk mengadakan mesin pencacah hijauan untuk membantu mereka dalam membuat amoniasi jerami padi dan silase hijauan. Peserta juga sangat senang menerima bantuan bibit hijauan pakan ternak berupa bibi lamtoro, Clitoria ternatea dan turi.

\section{PENUTUP}

Teknologi pengawetan pakan silase adalah teknologi yang mudah dan aplikatif untuk menjawab permasalahan kekurangan pakan pada saat musim kemarau di NTT. Teknologi ini juga akan sangat membantu dalam perbaikan manajemen produksi ternak ruminansia yang lebih baik.

Namun demikian, industri peternakan di NTT akan sangat berkembang jika teknologi pengawetan rumput dan hijauan lainnya dalam bentuk silase atau olahan lainnya dapat dimasyarakatkan. Populasi ternak akan meningkat dengan drastis dan demikian juga dengan produktivitas dan kesejahteraan peternak. 


\section{REFERENSI}

Adeniji, A.A., 2007. Effect of replacing groundnut cake with maggot meal in the diet of broilers. International Journal of Poultry Science. 6(11): 822-825.

Agunbiade, J.A., Adeyemi, O.A., Ashiru, O.M., Awojobi, H.A., Taiwo, A.A., Oke, D.B. and Adekunmisi, A.A., 2007. Replacement of fish meal with maggot meal in cassava-based layers' diets. The Journal of Poultry Science. 44(3): 278-282.

Aniebo, A.O., Erondu, E.S. and Owen, O.J., 2008. Proximate composition of housefly larvae (Musca domestica) meal generated from mixture of cattle blood and wheat bran. Department of Animal Science and Fisheries, University of Port Harcourt. Nigeria.

Awoniyi, T.A.M., Aletor, V.A. and Aina, J.M., 2003. Performance of broiler-chickens fed on maggot meal in place of fish meal. International Journal of Poultry Science. 2: 271274.

Bondari, K. and Sheppard, D.C., 1981. Black soldier fly larvae as a feed in commercial fish production. Aquaculture 24: 103-109.

Calvert, C.C. \& Martin, R.D.A., 1969. Housefly pupae as food for poultry. Journal of Economical Entomology. 62:938-939.

Charlton, A.J., Dickinson, M., Wakefield, M.E., Fitches, E., Kenis, M., Han, R., Zhu, F., Kone, N., Grant, M., Devic, E., Bruggeman, G., Prior, R. and Smith, R., 2015. Exploring the chemical safety of fly larvae as a source of protein for animal feed. Journal of Insects as Food and Feed 1: 7-16.

De Koning, A.J., 2005. Properties of South African fish meal: A review. South African Journal of Science 101.

De Marco, M., S. Martinez, F. Hernandez, J. Madrid, F. Gail, L. Rotolo, M. Belforti, D. Bergero, H. Katz, S. Dabbou, A. Kovitvadhi, I. Zoccarato, L. Gasco and A. Schiavone. 2015. Nutritional value of two insect larval meals (Tenebrio molitor and Hermetia illucens) for broiler chickens: Apparent nutrient digestibility, apparent ileal amino acid digestibility and apparent metabolizable energy. Animal Feed Sci and Technol. 209:211-218. DOI: http://dx.doi.org/10.1016/j.anifeedsci.2015.08.006 
Fasakin, E.A., Balogun, A.M. and Ajayi, O.O., 2003. Evaluation of full-fat and defatted maggot meals in the feeding of clariid catfish, Clarias gariepinus, fingerlings. Aquaculture. Research. 34(9): 733-738.

Flegal, C.J., Sheppard, C.C. and Dorn, D.A., 1972. The effects of continuous recycling and storage on nutrient quality of dehydrated poultry waste (DPW). Waste management research. Proceedings of the 1972 Cornell Agricultural waste management conference. Ithaca, New York. P 295-300.

Khusro, M., Andrew, N.R. and Nicholas, A., 2012. Insects as poultry feed: a scoping study for poultry production systems in Australia. World's Poultry Science Journal 68: 435-446.

Makkar, H.P.S., Tran, G., Heuzé, V. and Ankers, P., 2014. State-of-the-art on use of insects as animal feed. Animal Feed Science and Technology 197: 1-33.

Ncobela, C. N. dan M. Chimonyo. 2015. Potential of using non-conventional animal protein sources for sustainable intensification of scavenging village chickens: A review. Animal Feed Sci and Technol. 208: 1-11. DOI: http://dx.doi.org/10.1016/j.anifeedsci.2015.07.005

Newton, G.L., Booram, C.V., Barker, R.W. and Hale, O.M., 1977. Dried Hermetia illucens larvae meal as a supplement for swine. Journal of Animal Science. 44(3): 395-400.

Ogunji, J.O., Kloas, W., Wirth, M., Schulz, C. and Rennert, B., 2006. Housefly maggot meal (magmeal): An emerging substitute of fishmeal in tilapia diets. Conference on international agricultural research for development. Deutscher Trapentag.

Ramos-Elorduy, J., Gonzalez, E.A., Hernandez, A.R. and Pino, J.M., 2002. Use of Tenebrio molitor (Coleoptera: Tenebrionidae) to recycle organic wastes and as feed for broiler chickens. Journal of Economic Entomology 95: 214-220.

St-Hilaire, S., Sheppard, C., Tomberlin, J.K., Irving, S., Newton, L., McGuire, M.A., Mosley, E.E., Hardy, R.W. and Sealey, W., 2007. Fly prepupae as a feedstuff for rainbow trout, Oncorhynchus mykiss. Journal of World Aquaculture Society. 38(1): 59-67.

Teotia, J.S. \& Miller, B.F., 1974. Nutritive content of house fly pupae and manure residue. British Poultry Science. 15(2): 177-182.

Vantomme, P., 2015. Way forward to bring insects in the human food chain. Journal of Insects as Food and Feed 1: 121-129. 
Veldkamp, T., Van Duinkerken, G., Van Huis, A., Lakemond, C.M.M., Ottevanger, E., Bosch, G. and Van Boekel, M.A.J.S., 2012. Insects as a sustainable feed ingredient in pig and poultry diets - a feasibility study. Wageningen UR Livestock Research Report 638. 